\title{
Piotr Korduba
}

Instytut Historii Sztuki, Uniwersytet Adama Mickiewicza

ORCID: 0000-0001-7603-9858

\section{Polskie międzywojenne poradnictwo w zakresie wnętrz mieszkalnych jako obszar relacji niemiecko-polskich}

DOI: https://doi.org/10.26881/porta.2020.19.18

W 1928 r. Maria Morozowicz-Szczepkowska, znana aktorka i pisarka, opublikowała w ramach serii „Życie Praktyczne” wydawnictwa Bluszcz jedyny w swoim rodzaju poradnik Wnętrze polskiego domu dawniej a dziś'. Zawarła w nim - obok zaleceń dotyczących urządzania - sporo przemyśleń o przeszłości domu, ze szczególnym uwzględnieniem negatywnego wpływu czasów i warunków rozbiorowych i diagnozą aktualnej sytuacji, sformułowaną zresztą w quasi-higienicznym dyskursie o chorobie i kuracji. Pisała więc: „Odgrzebać Polskę dawną z obcej patyny i na tym gruncie budować Polskę nową - oto zadanie nie tylko prawodawcy i polityka, nie tylko artysty sporządzającego polskie tkaniny i sprzęty, odnawiającego wnętrze polskiego domu, zaśmieconego przez długotrwałą chorobę - niewolę - ale i obywatela, budującego i zdobiącego sobie dom. Przywróciliśmy polski język zgermanizowanym i zmoskwiczałym szkołom polskim; zniszczyliśmy niesławiące nas znamiona niewoli, cerkwie, obeliski, pomniki carów i kajzerów - z wnętrz naszych domów wydalić też musimy bezapelacyjnie wiedeńskie secesje, plusze, dywany berlińskie, tandety wszelkiego rodzaju i pochodzenia, zanieczyszczające nasze domy, które tym sposobem nie mają żadnego charakteru, są nieme, choć przecież posiadamy własny język: polską sztukę zdobniczą"2.

Autorka poradnika stwierdza, że polski dom, tak jak cały kraj, uległ chorobie - niewoli - i teraz musi przejść stosowną kurację, za którą odpowiedzialni są nie tylko przedstawiciele władzy i artyści, lecz także każdy obywatel. A kuracja ta powinna polegać na usunięciu obcych elementów wyposażenia i wprowadzeniu rodzimych ${ }^{3}$. Takie zalecenia pozostaną aktualne do końca

Maria Morozowicz-Szczepkowska, Wnętrze polskiego domu dawniej a dziś, Warszawa 1928. Ibidem, s. 8.

Warto w tym kontekście przypomnieć, że niemal w tym samym czasie w Niemczech pojawiła się książka o zbliżonej problematyce i utrzymana w podobnej poetyce, zatytułowana Das Gesicht des deutschen Hauses (München 1929), autorstwa architekta znanego ze swych związków z ideologią nazistowską, teoretyka i publicysty, Paula Schultze-Naumburga. Jego wcześniejszy poradnik dotyczący urządzenia mieszkania Häusliche Kunstpflege (Leipzig 1899), utrzymany 


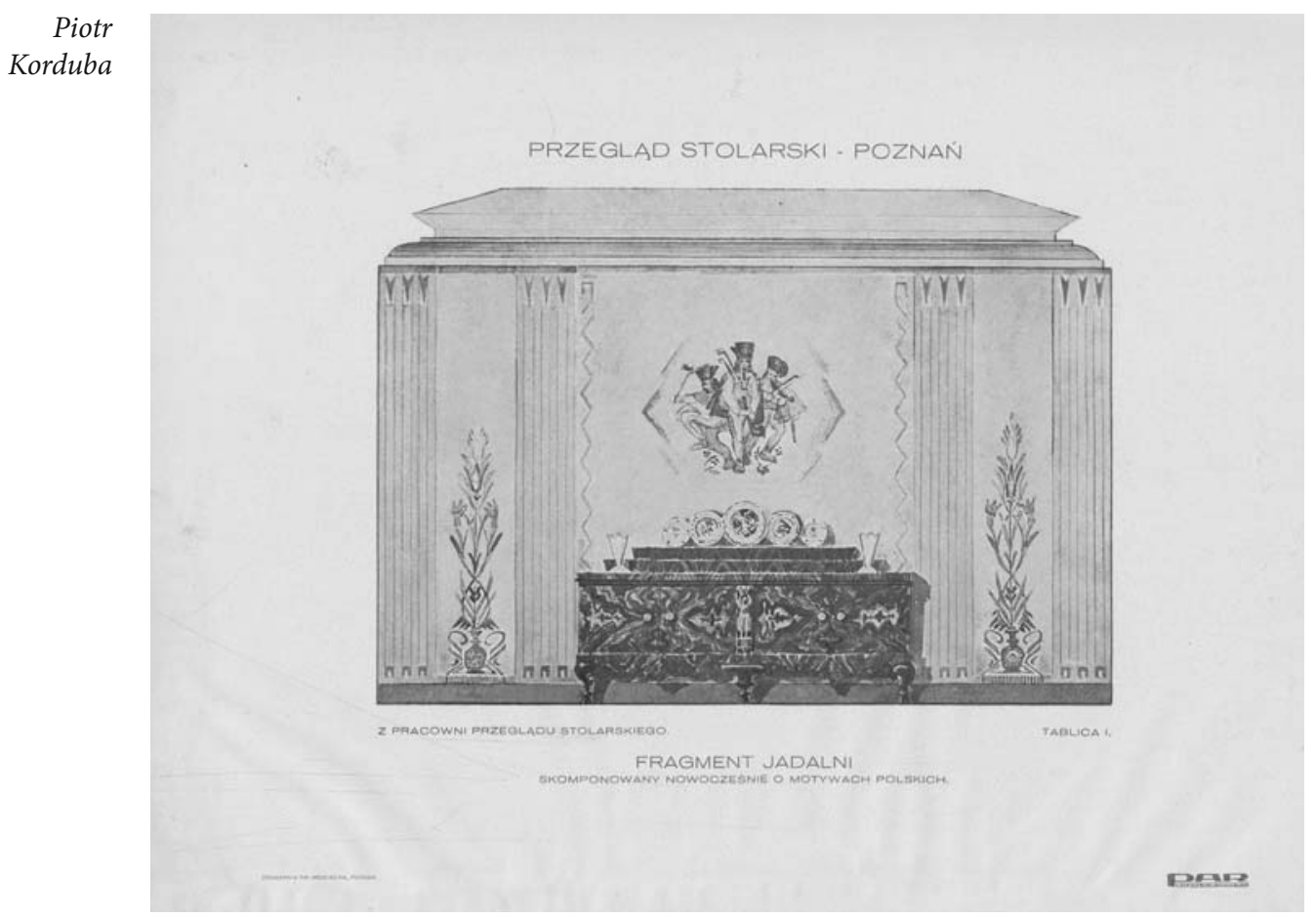

Il. 1. Projekt wnętrza „polskiego”, repr. za: „Przegląd Stolarski” 1928, nr 2, tabl. 1

okresu międzywojennego, choć ich motywacja ulegnie zasadniczej modyfikacji. Morozowicz-Szczepkowska zdefiniowała bowiem opozycję dawnego i współczesnego wnętrza jako wymianę „obcego" na „rodzime”, wskazując, że tym pierwszym są właśnie wpływy i materialna kultura trzech zaborców. Pośród nich pojawia się m.in. ten "germański/berliński”, który w moim przekonaniu, w dyskusjach nad polskimi wnętrzami doby międzywojennej będzie do końca interesującego nas okresu odgrywał rolę najistotniejszą, ale zarazem przejdzie najciekawszą transformację - od, nazwijmy go, wnętrza „obcego oprawcy” aż po wzór do naśladowania. Stanie się tak nie tylko z powodu "leczniczego" upływu czasu, który zatrze lata niewoli i wszelkie asocjacje z nią związane, lecz także na skutek ugruntowującej się koncepcji nowoczesnego wnętrza oraz funkcjonalnej i estetycznej przemiany, jaka się wraz z nimi dokonała. Warto bowiem zwrócić uwagę, że dla Morozowicz-Szczepkowskiej to, co obce i „zanieczyszczające”, odpowiada jednocześnie syntetycznej charakterystyce mieszczańskiego wnętrza przełomu wieków, wypełnionego sprzętami i przedmiotami zuniwersalizowanej seryjnej

jednak w zupełnie innym duchu, został opublikowany w Polsce pod tytułem Estetyka mieszkania (przeł. Antoni Krasnowolski, Warszawa 1904). Niezmienione w treści wydanie 2. ukazało się pod tytułem Jak urzadzić i ozdobić mieszkanie (1908). 
produkcji, utrzymanej w konwencji historyzującej lub secesyjnej estetyki. A więc to, co obce, jest zarazem tym, co w sensie wnętrzarskim jest stare. Ta bazująca na formule $z$ końca XIX w. funkcjonalno-estetyczna kondycja wnętrza była na ogół utożsamiana w naszym kręgu kulturowym z niezwykle spójnym - zarówno pod względem teoretyczno-ideowym, jak i wizualnym - wyobrażeniem o mieszczańskim wnętrzu niemieckim ${ }^{4}$. W ostatnich dekadach XIX w. ugruntował się jego wyrazisty obraz, oparty na recepcji form neostylowych, który generowała nie tylko wielka produkcja wnętrzarskiego wyposażenia, recypowana również przez polskich wytwórców i odbiorców ${ }^{5}$, lecz także stosowne publikacje ze słynnym, wznawianym opracowaniem Georga Hirtha Das deutsche Zimmer ${ }^{6}$. W pierwszej połowie XX w. wnętrze uległo oczywistym funkcjonalno-formalnym przekształceniom, ale nadal mieściło w sobie zespół społeczno-kulturowych wyobrażeń, zawierających się w tak nośnych dla niemieckiego społeczeństwa określeniach, jak das schöne Heim czy znanej również u nas wartości Gemütlichkeit ${ }^{7}$. Jednak wśród polskiej publiczności określone skojarzenia budziła przede wszystkim wizualna identyfikacja „niemieckiego" mieszkania utożsamiana $\mathrm{z}$ formami historycznymi. Można tu przywołać wypowiedź architekta Zenona Chrzanowskiego, który rozważając w 1911 r. sprawy odnowy rodzimego mieszkania, stwierdzał, że „przykłady takich zdobionych, pretensjonalnych i niewygodnych mebli pozostawiły nam style staroniemiecki i barokowy. Dlatego to szafy gdańskie, pomimo że są dziełami kunsztu stolarskiego i snycerskiego, nie są właściwym typem mebla"8. W późniejszych wypowiedziach z czasów tu omawianych to, co w wyposażeniu

4 O czym pisał ciekawie Andreas K. Vetter, Kommentar [w:] Das schöne Heim. Deutsche Wohnvorstellungen zwischen 1900 und 1940 in Bild und Text, Hg. Andreas K. Vetter, Heidelberg 1999, s. 89-102; Stefan Muthesius, The „altdeutsche” Zimmer, or Cosiness in Plain Pine. An 1870s Munich Contribution to the Definition of Interior Design, „Journal of Design History” 2003, vol. 4, s. 269-290.

5 Zagadnienia wpływu masowo wytwarzanych i zbywanych w państwach zaborczych elementów wyposażenia do mieszkań Polaków i innych narodowości zamieszkujących tereny zaborów nie były przedmiotem studiów i nie można ich łączyć z naukową refleksją nad np. recepcją nurtów rzemiosła artystycznego przez polskich twórców, szkoły czy wytwórnie artystyczne. Zjawisko to zdaje się funkcjonować w świadomości badaczy na poziomie niezweryfikowanej naukowo oczywistości, choć istnieją już publikacje poważniej je rejestrujące, zob. m.in. Waldemar Karolczak, Poznańskie magazyny mebli i ich oferta na przełomie XIX/XX wieku, „Kronika Miasta Poznania" 1999, nr 4, s. 76-92.

6 Georg Hirth, Das deutsche Zimmer der Renaissance. Anregungen zu häuslichen Kunstpflege, München 1882. Wydanie z 1899 r. opatrzone było tytułem Das deutsche Zimmer der Gotik und Renaissance, des Barock-, Rococo-, und Zopfstils Anregungen zu häuslichen Kunstpflege (Leipzig 1899).

7 Vetter, Kommentar...

8 Zenon Chrzanowski, Kultura mieszkalna, Warszawa 1911, s. 18. Warto w tym miejscu przypomnieć, że meble gdańskie i neogdańskie od czasów zaborów aż po dwudziestolecie międzywojenne były przyczyną poważnego niemiecko-polskiego napięcia kulturowego, zob. Tadeusz Kruszyński, Sprzęty gdańskie i tzw. gdańskie, „Rzeczy Piękne” 1929, nr 2, s. 56; Piotr Korduba, Wnętrza gdańskie poza Gdańskiem [w:] Gust gdański, red. Bronisława Dejna, Jakub Szczepański, Gdańsk 2004, s. 150-164; idem, Danziger Möbel und Innenräume im 19. und 20. Jahrhundert und ihre polnischen und deutschen Konnotationen [w:] Visuelle Erinnerungskulturen und 
Piotr Korduba

wnętrza bywało niemieckie, było równoznaczne z tym, co kiczowate, w złym guście ${ }^{9}$. Skojarzenia takie były jeszcze rozpowszechnione w drugiej połowie lat trzydziestych: „Prawdopodobnie przez dłuższy czas teren nasz będzie polem ścierania się wielu kierunków przeniesionych z zewnątrz, tymczasem zaś mamy przede wszystkim za zadanie wyplenienie całego szeregu naleciałości okresu minionego, półinteligenckiej produkcji według wzorów eksportowych z Berlina" ${ }^{\prime 10}$.

W latach dwudziestych istotne były nie tylko te negatywne, ogólne skojarzenia, lecz także realne poczucie wpływu niemieckiej kultury wnętrza i elementów jego wyposażenia na polskiego odbiorcę, szczególnie na terenach, które z powodów geopolitycznych były na ten wpływ najbardziej narażone. Odpowiedź na to zagrożenie stanowiła wystawa Wnętrze domu, zorganizowana w 1928 r. w Katowicach przez Śląskie Towarzystwo Wystaw i Propagandy Gospodarczej. W zakresie niemiecko-polskiej „rywalizacji” wnętrzarskiej było to wydarzenie szczególne, ponieważ jego intencja nie była domyślna, jak w przypadku wielu innych wystawienniczych pokazów, łącznie z tymi największymi (np. Powszechna Wystawa Krajowa), ale została sformułowana wprost i bezpośrednio: „Ponieważ poza tym Górny Śląsk stał dotychczas pod wrażeniem smaku niemieckiego, jeśli chodziło o kulturę mieszkaniową, stało się koniecznością przyśpieszenie procesu zbliżenia Śląska ku krajowej wytwórczości, szczególnie w dziale artystycznym i zdobniczym, i dlatego Towarzystwo dołożyło wszelkich starań, by szerokim masom ludności śląskiej umożliwić poznanie z jak najdodatniejszej strony walorów polskiej produkcji w wyżej wymienionych działach”" Wystawa miała stanowić „pokojową rewolucję” i dawać nadzieję, że przemysł będzie mógł się oprzeć na motywach polskich, a duża siła nabywcza na Śląsku spowoduje, że rodzime wyroby zaczną funkcjonować w społeczeństwie $^{12}$. Wystawa nieprzypadkowo została zorganizowana właśnie w tym regionie - jego zarządca, wojewoda Michał Grażyński, był wyraźnie zorientowany na rywalizacje z $\mathrm{Niemcami}^{13}$.

Geschichtskonstruktionen in Deutschland und Polen 1800 bis 1939, Hg. Robert Born, Adam S. Labuda, Beate Störtkuhl, Warszawa 2006, s. 305-321.

9 Morozowicz-Szczepkowska, Wnętrze polskiego domu..., s. 8, 18, 30; Stefan Szuman, Mieszkanie polskie a samodziały wileńskie, „Tęcza” 1929, nr 16, s. 9; idem, Mieszkanie polskie a samodziały wileńskie, „Rzeczy Piękne” 1929, nr 3, s. 94.

10 Kazimierz Prószyński, Poszukiwanie definicji, „Architektura i Budownictwo” 1936, nr 3, s. 76.

11 Oficjalne sprawozdanie $z$ wystawy „Wnętrze domu” i technika na uslugach gospodarstwa domowego, „Rzeczy Piękne” 1929, nr 1, s. 28-29.

12 Irena Huml, Ład w Katowicach [w:] Polskie art déco, red. Zbigniew Chlewiński, Płock 2015, s. 26-41.

13 Trzeba jednak wspomnieć, że te zamierzenia dokonały się w cieniu pewnych niuansów, takich jak choćby wielkie trudy organizacyjne i ostateczna konieczność sprowadzenia namiotu dla wystawców z Berlina. Ponadto pojawiło się także kilka niemieckich firm z bardzo poważnymi pokazami, a jednej z nich, czerpiącej z niemieckich wzorów, przyznano złoty medal, zob. Wystawa „Wnętrze domu” w Katowicach, „Rzeczy Piękne” 1928, nr 10, s. 127-128. 
Warto zauważyć, że na wystawie w Katowicach były obecne m.in. wyroby Spółdzielni Artystów „Ład”, której członkowie na różne sposoby czerpali inspiracje z kultury ludowej ${ }^{14}$. Według Morozowicz-Szczepkowskiej to właśnie elementy ludowej wytwórczości miały w zalecanym przez nią kuracyjnym działaniu moc „uzdrawiającą”: „Nawet brzydki, stary mebel, pokryty nową polską tkaniną, pięknieje i nabiera miłego, swojskiego wyglądu. Zdzieramy więc ze starych foteli i kanap »dywanowe«, ponure, brzydkie w deseniu i kolorze, niemieckie szkarady, zastępując je tkaniną lnianą »Przemysłu Ludowego « lub »Ładu«, i zamiast starego, brzydkiego, drażniącego nasze nerwy sprzętu - mamy prześliczny, wesoły, swojski mebel, wnoszący nam do mieszkania powiew oryginalnej twórczości

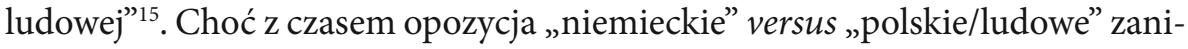
kła, to właśnie elementy ludowego wyposażenia we współczesnym wnętrzu należały ówcześnie do tych najpowszechniej zalecanych i obdarzanych regeneracyjną mocą (do czego jeszcze z perspektywy interesującego nas kontekstu powrócimy). Przyczyn takiego stanu rzeczy było kilka i ich akcenty różnie się rozkładały w zależności od czasu. O ile w latach dwudziestych traktowano sztukę ludową bardzo często jako rezerwuar motywów dla sprzętów i elementów wyposażenia wnętrz, o tyle w kolejnej dekadzie, wraz z krytyką takiego stanowiska, zwrócono się w stronę strukturalnie i państwowo koordynowanej wytwórczości ludowej, która miała znaleźć zastosowanie we wnętrzu, co z kolei powinno stymulować jej niezmienną żywotność, a wiejskiej ludności przynieść środki do życia ${ }^{16}$. Na marginesie naszych rozważań warto wspomnieć, że w narracji o żywotności polskiej wytwórczości ludowej, obok wątku opozycji tego zjawiska wobec współczesnej kultury z jej industrializacją i technicyzacją ${ }^{17}$, pojawia się utożsamianie tych wymiarów cywilizacji właśnie z Niemcami, gdzie (podobnie jak na ziemiach polskich znajdujących się pod najsilniejszym wpływem państwa niemieckiego, np. Polsce Zachodniej) zauważano zanik wytwórczości ludowej ${ }^{18}$.

Porad dotyczących stosowania sztuki ludowej we współczesnym wnętrzu było wiele ${ }^{19}$. Szczególnie mocno akcentowano kwestię wykorzystywania tkanin

14 Spółdzielnia Artystów „Lad” 1926-1996, t. 1, red. Anna Frąckiewicz, Warszawa 1998; Ewa Klekot, „Ład” i lud. Twórcy sztuki ludowej a twórcy „Ładu” [w:] Spółdzielnia Artystów „Ład”, t. 2, red. Anna Frąckiewicz, Narodowe Centrum Kultury [w druku].

15 Morozowicz-Szczepkowska, Wnętrze polskiego domu..., s. 30.

16 Piotr Korduba, Ludowość na sprzedaż. Towarzystwo Popierania Przemysłu Ludowego, Cepelia, Instytut Wzornictwa Przemysłowego, Warszawa 2013.

17 Ibidem, s. 53-55.

18 Stanisław Kopczyński, Znaczenie ekonomiczne przemysłu ludowego w Polsce, „Polska Gospodarcza" 1930, z. 3, s. 93.

19 Zob. Janina Jankowska-Orynżyna, Sztuka ludowa w małym mieszkaniu, „Dom-OsiedleMieszkanie" 1930, nr 3, s. 32-33; Ludwika Rettingerowa, Przemysł i sztuka ludowa w mieszkaniu wspótczesnym, „Dom - Osiedle - Mieszkanie” 1931, nr 1, s. 20-23; C.Z., Tkanina Iniana w nowoczesnym wnętrzu, „Wnętrze” 1931, nr 3, s. 49-50; Halina Mamelkowa, Korzystajmy z okien, „Pani Domu" 1933, nr 6, s. 116-117; Helena Wolska, Ludowe tkactwo lniane i kilimy Szkót Społecznych Przemysłu Domowego, „Pani Domu” 1933, nr 8, s. 161; eadem, Len w mieszkaniu, „Pani Domu” 1934, nr 2, s. 25-27; H.W. [Helena Wolska], „Konopie - len - wetna” na Targach Wschodnich 
Piotr Korduba

regionalnych. Zalecano ich użycie w wystroju domu po to, by nadać wnętrzu indywidualny, polski charakter ${ }^{20}$, wesprzeć krajową produkcję $e^{21}$ lub by zrobić "propagandę wsi polskiej w międzynarodowym porcie"22 - jak głoszono przy okazji otwarcia sklepu Spółdzielni Artystycznej „Rzut” w 1937 r. w Gdyni. Niekiedy motywy ludowe we wnętrzu niemal wprost uznawano za przejaw szczególnej postawy wobec ojczyzny: „Wystawa-targi pod nazwą »Len Polski«, która odbywa się w tym czasie w stolicy, daje wielką okazję do wykazania naszego najrozumniejszego patriotyzmu przez zaznajomienie się na niej z polskim przemysłem lniarskim oraz okazanie realnego poparcia podjętej akcji przez wprowadzenie wyrobów lnianych do każdego domu"23.

$\mathrm{O}$ ile ten aspekt nie miał właściwie żadnego związku z narodowo-kulturowymi napięciami na gruncie niemiecko-polskim, o tyle twórczość ludowa $\mathrm{z}$ wybranych, przygranicznych obszarów już takowe wywoływała. Najsłynniejsza był chyba kwesta tkanin dwuosnowowych, znanych zarówno na Podlasiu, jak i na terenach Prus Wschodnich, które stały się obszarem zainteresowania nie tylko polskich animatorów tradycyjnego tkactwa, ze słynną Eleonorą Plutyńskąa ${ }^{24}$ lecz także niemieckich (Erna Koller) ${ }^{25}$. Poświęcona im publikacja Konrada Hahma urosła wręcz do rangi politycznego problemu, wywołując dyskusję nad narodową przynależnością owych tkanin ${ }^{26}$. Podobne głosy dało się słyszeć w sprawie wytwórczości kaszubskiej i jej tożsamości kulturowej ${ }^{27}$.

we Lwowie, „Pani Domu” 1934, nr 9, s. 211; eadem, Kilka motywów przemysłu ludowego do dekoracji mieszkania, „Pani Domu” 1934, nr 10, s. 231-233; Przemysł ludowy we współczesnym wnętrzu, „Arkady” 1936, nr 5, s. 254-255.

20 Szuman, Mieszkanie polskie...

21 Ozdabiajmy mieszkanie wyrobami polskiej pracy i z polskiego surowca, „Pani Domu” 1933, nr 6, s. 131; Maria Romanowa, Krajowe czy zagraniczne?, „Pani Domu” 1933, nr 11, s. 205-207; Jadwiga Prażmowska, Czy kupować wyroby ludowe?, „Pani Domu” 1937, nr 12, s. 236-238.

${ }_{22}$ Katarzyna Kluczwajd, Spojrzenie na Rzut. O wyposażeniu domu i wzornictwie w toruńskim wydaniu, Toruń 2002, s. 15-16; zob. też Korduba, Ludowość na sprzedaż..., s. 72-74.

23 Iza Mandukowa, Len w każdym domu, „Pani Domu” 1934, nr 6, s. 136.

24 Aleksander Błachowski, Ludowe dywany dwuosnowowe w Polsce, Torun 1990.

25 Ursula Kircher, Von Hand gewebt. Eine Entwicklungsgeschichte der Handweberei im 20. Jahrhundert, Marburg 1986, s. 41.

26 Konrad Hahm, Ostpreußische Bauernteppiche, Jena-Berlin 1937; Ewa Gładkowska, Ostpreußische Bauernteppiche - Die Geschichte einer Polemik über Ihre Herkunft [w:] Die Etablierung und Entwicklung des Faches Kunstgeschichte in Deutschland, Polen und Mitteleuropa (anlässlich des 125-jährigen Gründungsjubiläums des ersten Lehrstuhls für Kunstgeschichte in Polen), Hg. Wojciech Bałus, Joanna Wolańska, Birte Pusback, Warszawa 2010, s. 557-569.

27 Tadeusz Seweryn, Kaszubski przemysł domowy, „Rzeczy Piękne” 1925, nr 6-8, s. 119-121. O tej problematyce w odniesieniu do czasów wcześniejszych zob. Edmund Kizik, Współpraca Izydora Gulgowskiego z gdańskim Kunstverein w roku 1909. U źródeł ceramiki nowokaszubskiej, „Kwartalnik Historii Kultury Materialnej” 2015, z. 3, s. 495-510; idem, Verein für kaschubische Volkskunde w latach 1907-1914. Ludoznawstwo kaszubskie między niemieckościa a polskością, „Zapiski Historyczne” 2015, z. 2, s. 31-54. 
Powracając do kwestii konstruowania wizerunku unikatowego polskiego wnętrza, warto zadać pytanie, czy istniały w świadomości propagatorów odnowy takie elementy urządzenia czy wystroju, które mogły o tym stanowić. Śledząc międzywojenne publikacje, należy zauważyć, że tak właśnie było - przykładem były kilimy i grafika, czego zresztą nie ukrywano ${ }^{28}$. Kilimy od przełomu wieków wzbudzały na terenach polskich duże zainteresowanie ${ }^{29}$, a w okresie międzywojennym pojawiło się o nich sporo publikacji. Z jednej strony były to opracowania dotyczące specyfiki, dziejów i aktualnego stanu artystycznej wytwórczości ${ }^{30}$. Z drugiej strony powstawały teksty dotyczące możliwości wykorzystania tych dekoracyjnych dywanów we współczesnym wnętrzu polskim. Kilimy były więc przedstawiane jako „piękny łan polskiego pejzażu”31, „które tchną świeżą tężyzną zdrowego narodu, możemy wierzyć w wielką przyszłość polskiego przemysłu artystycznego" 32 oraz "jako jedna z dominujących nut dekoracyjnych"33. Uważano wprost, że w żadnej dziedzinie przemysłu artystycznego nie dokonał się w ostatnich latach tak duży postęp jak tu ${ }^{34}$. Twierdzono, że kilimy są polskim towarem eksportowym ${ }^{35}$. Wraz z innymi polskimi tkaninami „nadają wnętrzom cechy swojskie i [...] na wskroś nowoczesne, a zarazem stosują się doskonale prawie do każdego z umeblowań „stylowych”36. Zalecano, aby właśnie kilimami uzupełnić wnętrza, w tym te, w których (jak w hotelach czy akademikach) przebywa się czasowo i w których często dekorację stanowią właśnie wyroby obce. Jako przykład wskazano polskie stowarzyszenie YMCA, które ozdobiło już swoje pokoje pięknymi kilimami ${ }^{37}$. Szczególne miejsce w tych rekomendacjach zajmowały kilimy tkane przez

28 Dzisiejsze mieszkanie. Katalog pokazu. Miejskie Muzeum Przemysłu Artystycznego, Lwów, kwiecień-maj 1930, oprac. Henryk Cieśla, Lwów 1930, s. 3.

29 Irena Huml, Warsztaty Krakowskie, Wrocław-Warszawa-Kraków 1973; eadem, Polska sztuka dekoracyjna XX wieku, Warszawa 1978, s. 39-41, 104-105, 129-138; Halina Jurga, Kilimy, gobeliny, dywany [w:] Spółdzielnia Artystów..., s. 154-179; Kilimy polskie od XVIII do XX wieku, red. Maria Teresa Michałowska-Barłóg, Poznań 2008; Warsztaty Krakowskie 1913-1926, red. Maria Dziedzic, Kraków 2009; Piotr Korduba, Wystawa tkanin „Polska sztuka tkacka” w Instytucie Propagandy sztuki w 1938 r. [w:] Tkaniny orientalne w Polsce - gust czy tradycja?, red. Beata Biedrońska-Słotowa, Warszawa 2011, s. 23-32.

30 K.W. [Kazimierz Witkiewicz], Stan dzisiejszego przemystu kilimkarskiego, „Rzeczy Piękne” 1922, nr 3, s. 34-36; Stefan Szuman, Kilim słowiański, kobierzec azjatycki, gobelin francuski, „Rzeczy Piękne” 1925, nr 5, s. 98-101; Maria Morozowicz-Szczepkowska, Tkaniny w Polsce, „Dom - Osiedle - Mieszkanie” 1929, nr 10-12, s. 47-51; Stefan Szuman, Dawne kilimy w Polsce i na Ukrainie, Poznań 1929.

31 K.W. [Kazimierz Witkiewicz], Stan dzisiejszego przemystu..., s. 34.

32 Kazimierz Witkiewicz, Rozwój polskiego kilimu, „Rzeczy Piękne” 1927, nr 7-8, s. 114.

33 Helena Wolska, O kilimach, „Pani Domu” 1937, nr 21, s. 401.

34 Tadeusz Seweryn, Kilimy Bogdana Tretera na P.W. K. wykonane w pracowni „Kilim” w Krakowie, „Rzeczy Piękne” 1929, nr 4-6, s. 129.

35 Władysław Skoczylas, Polska na wystawie międzynarodowej w Monzy, „Pani” 1923, nr $4-5$, s. $28-30$

$36 \quad$ Dzisiejsze mieszkanie..., s. 3.

37 Witkiewicz, Rozwój polskiego kilimu..., s. 113. 
Piotr Korduba

Spółdzielnię Artystów „Ład” - przypominano, że są one nie tyle precedensem, ile wspaniałym ogniwem w długiej historii tego medium artystycznego i wyposażenia wnętrz w Polsce ${ }^{38}$. Drugim elementem była wspomniana grafika, którą promowano m.in. jako pozytywny odpowiednik groźnego „landszaftu”39. $\mathrm{W}$ okresie międzywojennym pokazywano ją - podobnie jak kilimy - w aranżacjach wnętrz na wystawach krajowych i zagranicznych. Kreowano na nią modę jako na medium demokratyczne, przystępne cenowo oraz odpowiednie do nowych, mniejszych mieszkań, w odróżnieniu od sporych gabarytowo obrazów w złotych ramach. Nie bez znaczenia były także jej polska, nierzadko ludowa tematyka i możliwość subskrypcji w różnych czasopismach ${ }^{40}$.

W kraju i za granicą odbyły się dziesiątki pokazów polskich kilimów i grafik. Nie można też przemilczeć - ze względu na rangę i ideowy komunikat - ich szczególnej obecności w Zamku Prezydenta RP w Wiśle, zbudowanego dla Ignacego Mościckiego. Projekt przygotował w 1931 r. Adolf Szyszko-Bohusz ${ }^{41}$. Rezydencja wzniesiona na przygranicznym Śląsku przez ultrapolskiego architekta, wyraźnie odcinała się od powszechnej wówczas tradycji polskiego dworu uznawanej za wyraz narodowego stylu. Szyszko-Bohusz zaproponował bowiem formułę nowoczesnej willi-warowni na górskim zboczu, co nie było bez znaczenia w kontekście niemieckiego sąsiedztwa. Wnętrza zaprojektowano z wykorzystaniem luksusowych modernistycznych mebli z metalowych rurek, nowoczesnej technologicznie infrastruktury, przełamując je dyskretnie kilimami i grafikami, które miały złagodzić tę międzynarodową, technicystyczną konwencję i nadać przestrzeni bardziej tożsamościowy charakter ${ }^{42}$.

Pod koniec latach dwudziestych XX w. w rozważaniach nad wnętrzem zaczął się pojawiać - równolegle do przywoływanych przykładów - zupełnie inny niemiecki horyzont, zyskując na znaczeniu w kolejnym dziesięcioleciu. Nie był on ufundowany ani na politycznych resentymentach, ani na prostych skojarzeniach z mieszkaniem „z poprzedniej epoki”, ani tym bardziej na uproszczonych asocjacjach z kiczem i złym gustem. Wręcz przeciwnie, niemieckie osiągnięcia w zakresie kultury współczesnego wnętrza stały się dla Polaków

38 Jadwiga Korzeniowska, $O$ „Ładzie”, „Kobieta Współczesna” 1928, nr 8, s. 12-14; nr 9, s. 11-13.

39 Zob. Katarzyna Kulpińska, Każdy może kupić sobie oryginalny drzeworyt. Grafika na ścianie mieszkania $w$ latach dwudziestych i trzydziestych dwudziestego wieku [w:] Polskie art déco, red. Zbigniew Chlewiński, Płock 2017, s. 155-174.

40 Zob. też Izabela Mościcka, Obraz, grafika czy malowidło ścienne [w:] Polskie art déco..., s. 185.

${ }^{41}$ Ewa S. Chojecka, Pomiędzy historia a nowoczesnością. Treści ideowe Zamku Prezydenta RP w Wiśle [w:] Zamek Prezydenta Rzeczypospolitej $w$ Wiśle / The Castle of the President of The Republic of Poland in Wisła, red. Jacek Purchla, Kraków 2005, s. 11-20.

${ }_{42}$ Zygmunt Świechowski, Awangarda na usługach elity władzy. Wystrój i mobiliaż Zamku Prezydenta RP w Wiśle [w:] Zamek Prezydenta..., s. 221-228. Co było zresztą krytykowane przez zwolenników całkowitego unowocześnienia i kosmopolityzacji wnętrz, zob. Stanisław Świerz-Zalewski, Zameczek w Wiśle, „Architektura i Budownictwo” 1931, nr 5-6, s. 173; Hubert Bilewicz, Meble w Zameczku prezydenta Ignacego Mościckiego w Wiśle. Kwestia chronologii, inwentarza i atrybucji, „Porta Aurea” 2009, t. 7-8, s. 284-345 (o kilimach i grafikach zob. s. 318). 
punktem odniesienia i nie tylko chętnie je prezentowano, lecz na ogół wprost określano jako wzór do naśladowania. Bez upraszczającego uogólnienia można powiedzieć, że niemiecka kultura mieszkalna stała się synonimem racjonalności, funkcjonalności, redukcji reprezentacyjności i ozdobności na rzecz funkcji i minimalistycznego wyposażenia, a niekiedy po prostu szeroko rozumianej nowoczesności ${ }^{43}$. Tego rodzaju opinie były wyrażane na ogół przez przedstawicieli środowisk fachowych - architektów, można je było znaleźć też w kobiecym poradnictwie domowym ${ }^{44}$. Na bieżąco śledzono najnowsze osiągnięcia $w$ tym zakresie, relacjonując - najczęściej pozytywnie czy wręcz entuzjastycznie - niemieckie ekspozycje. Na łamach czasopisma „Kobieta Współczesna” doceniona została berlińska ekspozycja Bauen und Wohnen z 1928 r. ${ }^{45}$ Bardzo wysoko oceniono nowości w zakresie form i materiałów prezentowane na wrocławskiej wystawie Werkbundu, odbywającej się niemal w tym samym czasie co poznańska Powszechna Wystawa Krajowa ${ }^{46}$. Podobnie było w przypadku wnętrz pokazywanych podczas berlińskiej wystawy budowlanej w $1931 \mathrm{r}^{47}$ Architekci przyznawali się do ciekawości i „wzajemnego zrozumienia się z najbliższymi sąsiadami”"48. Inne doświadczenia niemieckie również ujmowały praktycznością i funkcjonalizmem ${ }^{49}$. Nie obawiano się dostrzegać w polskim wzornictwie podobieństw do estetyki niemieckiej. O ile w przypadku wystawy Sztuka wnętrza z 1936 r. jeden z recenzentów potraktował te zbieżności jako brak obecności osiągnięć indywidualnych, krajowych ${ }^{50}$, o tyle wobec ekspozycji Meble wnętrz mieszkalnych odbywającej się w Instytucie Propagandy Sztuki” w 1937 r. analogie te były wartościowane pozytywnie ${ }^{51}$. Bez aprobatywnego echa nie przeszły takie niemieckie dokonania, jak konstruowanie mebli z metalowych rurek ${ }^{52}$, funkcjonalna kuchnia (Barbara Brukalska) ${ }^{53}$ czy ukonstytuowanie się nowego

43 Te osiągnięcia oraz aspiracje w zakresie kultury zamieszkiwania syntetycznie charakteryzuje np. Andreas K. Vetter, Die Befreiung des Wohnens. Ein Architekturphänomen der 20er und 30er Jahre, Berlin 2000. Por. też Dzisiejsze mieszkanie..., s. 5.

44 J. Dominowska, Wystawa budowlano-mieszkaniowa, „Kobieta Współczesna” 1928, nr 52-53, s. 21-23; „Pani Domu” 1933, nr 1, s. 13.

45 Dominowska, Wystawa budowlano-mieszkaniowa...

46 „Dom-Osiedle-Mieszkanie” 1929, nr 7, s. 28-29; Edgar Norwerth, Wystawa mieszkaniowa we Wrocławiu, „Architektura i Budownictwo” 1929, nr 9, s. 319-336; A.B., Wystawa „Werkbundu” we Wrocławiu, „Rzeczy Piękne” 1930, nr 4-6, s. 71.

${ }_{47}$ Wystawa berlińska. Mieszkanie współczesne, „Dom - Osiedle - Mieszkanie” 1931, nr 8, s. 20-24.

48 Norwerth, Wystawa mieszkaniowa we Wrocławiu, s. 336.

49 Jadwiga Tittenbrunówna, Wnętrze mieszkalne, „Pani Domu” 1934, nr 4, s. 76-79.

50 Witołd Bunikiewicz, Wystawa „sztuki wnętrza”, „Kurier Warszawski” 1936, nr 60, s. 16.

51 Zygmunt Skibniewski, Architektura wnętrza. Uwagi o wystawie w Instytucie Propagandy Sztuki, „Arkady” 1937, nr 5, s. 236, 239.

52 Piotr M. Lubiński, Mebel metalowy w mieszkaniu, „Dom-Osiedle-Mieszkanie” 1931, nr 12, s. 12-16; M.K., Meble stalowe we wnętrzach Zameczku Pana Prezydenta Rzeczypospolitej Polskiej w Wiśle, „Wnętrze” 1931, nr 1, s. 4-9.

53 Marta Leśniakowska, Modernistka w kuchni. Barbara Brukalska, Grete Schütte-Lihotzky $i$ „polityka kuchenna” (wstęp do architektury modernizmu), „Konteksty. Polska Sztuka Ludowa” 


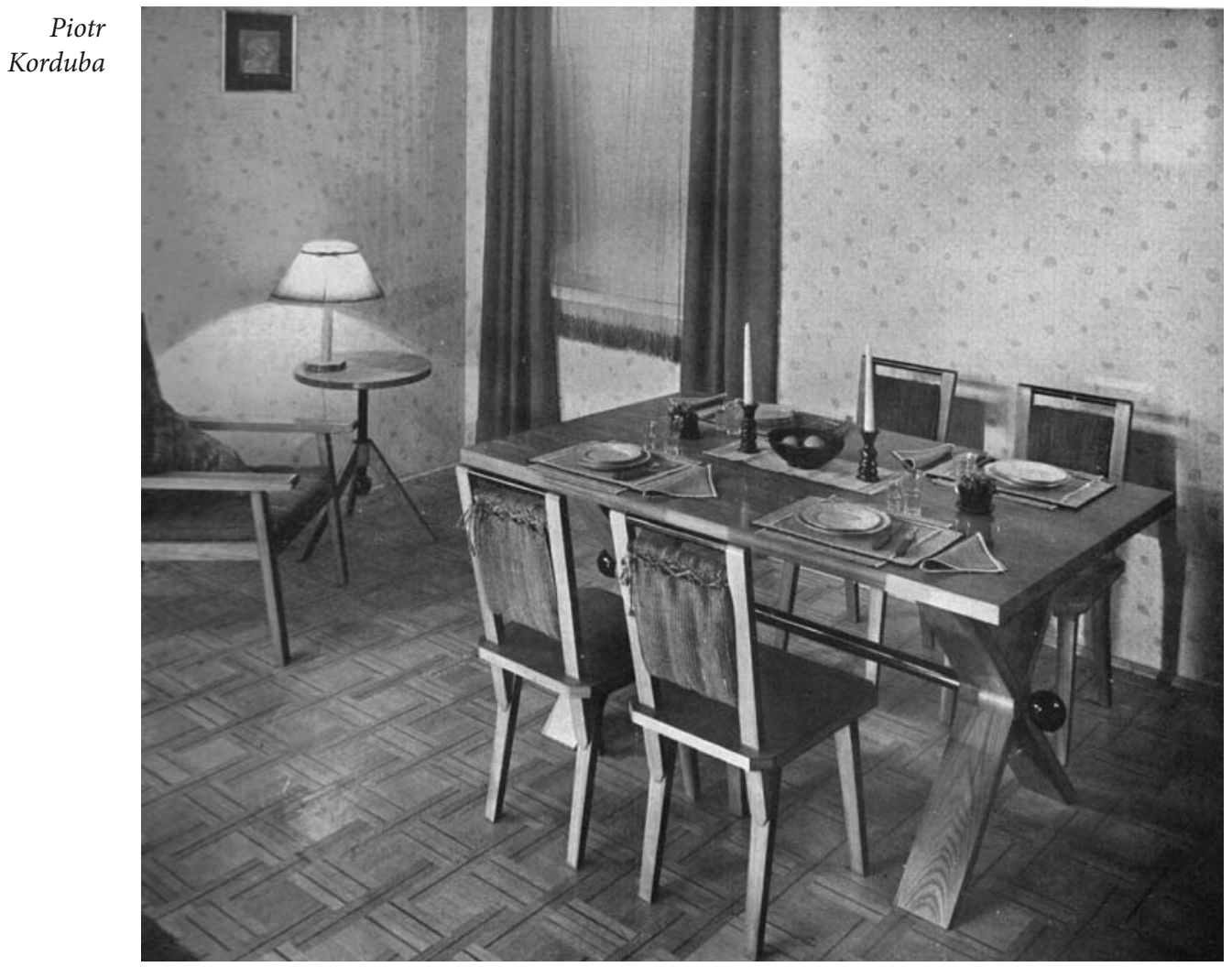

Il. 2. Meble projektu Stefana Sienickiego na wystawę „Meble wnętrz mieszkalnych” w Instytucie Propagandy Sztuki w Warszawie, 1937, według recenzenta „Arkad” utrzymane w duchu niemieckiego modernizmu, repr. za: „Arkady” 1937, nr 5, s. 236

specjalistycznego zawodu architekta wnętrz - pojawianie się specjalności obserwowano też w Polsce (Barbara Brukalska) ${ }^{54}$. Na łamach specjalistycznych czasopism rekomendowano fachowe niemieckie publikacje dotyczące architektury mieszkalnej, w tym wnętrz i ich wyposażenia ${ }^{55}$. W latach trzydziestych te same czasopisma chętnie ilustrowały porady wnętrzarskie fotografiami zaczerpniętymi z zagranicznych wydawnictw, $w$ tym również niemieckich ${ }^{56}$. Wśród praktycznych porad udzielanych polskich stolarzom w pierwszym numerze czasopisma „Przegląd Stolarski” (Organ Związków Polskich Cechów Stolarskich), pojawiły się zalecenia, aby nie stronić od śledzenia branżowych zagranicznych

2004, nr 1-2, s. 179-196.

54 Irena Jabłowska, Nowe drogi. Rozmowa z p. Barbarą Brukalską, „Kobieta Współczesna” 1928, nr 33, s. 14-16.

55 „Dom-Osiedle-Mieszkanie” 1929, nr 5, s. 26-28; Z książek i wydawnictw, „Dom-OsiedleMieszkanie" 1935, nr 7, s. 20-23.

56 J. Goldscheider, Urzq̨dzanie wnętrz, „Dom-Osiedle-Mieszkanie” 1936, nr 8, s. 2-16. 
czasopism, „przede wszystkim niemieckich”. Zauważano jednocześnie, że dla młodszej generacji problemem może być bariera językowa ${ }^{57}$.

Za symboliczny i zarazem bardzo jednoznaczny głos akceptacji tego, co się dzieje w niemieckim wnętrzarstwie, można uznać artykuł $O$ nowy styl w niemieckim meblarstwie, który ukazał się na łamach słynnych "Arkad” w 1937 r. ${ }^{58}$ Jego autor nie wychwala całej niemieckiej wytwórczości i projektowania. Zauważa, że meble spod znaku Bauhausu „pomimo pozornie nieskomplikowanych form, bynajmniej nie były proste i jest rzeczą co najmniej wątpliwą, czy prosty człowiek, tzw. "człowiek z tłumu «, mógł się wśród nich czuć dobrze" 59 , ale zarazem dostrzega funkcjonalność niemieckich mebli, docenia wykorzystywanie krajowego materiału do ich produkcji oraz niską cenę, a nawet wyciągnięcie znakomitej lekcji z tego, co powinno być naturalne i znamienne dla Polski - z mebla ludowego. „Dopiero przyczyny rzeczowe (jak pogoń za celowością) z jednej strony, a z innej teoretyczne uznanie sztuki ludowej za zdrowe źródło rodzimej kultury, wydźwignęły kształt mebli ludowych z ukrycia i odkryły je miastu" ${ }^{60}$. Już tylko marginalnie można wspomnieć, że nawet Gemütlichkeit, idiomatyczna wręcz wartość niemieckiego mieszkania, pojawiła się w charakterystyce polskich, nowoczesnych wnętrz jako doświadczenie pozytywne ${ }^{61}$.

Trudno o jednoznaczne rozpoznanie relacji niemiecko-polskich na gruncie międzywojennej kultury mieszkania. Z jednej strony nie sposób było bowiem uciec od napięć ufundowanych i ugruntowywanych na politycznych animozjach, tak samo jak trudno było uciec od sąsiedztwa z niemiecką kulturą i jej osiągnięciami oraz od ich realnego i pozytywnego wpływu na rozwój wielu polskich osiągnięć, zwłaszcza w dziedzinie architektury i kultury mieszkania. $Z$ drugiej strony wydaje się, że emocjonalny antagonizm, zauważalny w latach dwudziestych, słabł z upływem czasu, a jego miejsce zajmowała, przynajmniej w środowiskach eksperckich i opiniotwórczych, świadomość bliskiego istnienia dobrych wzorów, które z racji dostępności prasy fachowej, publikacji książkowych, a także wyjazdów na targi i wystawy, były powszechnie znane ${ }^{62}$. Te słabnące pod koniec lat trzydziestych dylematy trafnie ujął Zygmunt Skibniewski, pisząc o wystawie Meble wnętrz mieszkalnych w Instytucie Propagandy Sztuki w kontekście poszukiwania polskiego wyrazu wnętrz i niemieckich wpływów na projektantów IPS-u: „Wystawa odbywa się w czasach, kiedy świat coraz

57 Protokół z posiedzenia Zarządu Związku Polskich Cechów Stolarskich z dn. 10.04.1927, „Przegląd Stolarski” 1927, nr 2, s. 2-4.

${ }_{58}$ N. Eskul, O nowy styl w niemieckim meblarstwie, „Arkady” 1937, nr 8, s. 428-431.

59 Ibidem, s. 429.

60 Ibidem, s. 431

61 Edgar Nortwerth, Dom przy Klonowej, „Arkady” 1936, nr 1, s. 8.

62 Trudno powiedzieć, na ile akurat w tym konkretnym kontekście istotne było ocieplenie stosunków niemiecko-polskich po podpisaniu w 1934 r. deklaracji o niestosowaniu przemocy i wobec innych gestów tego rodzaju, zob. Marek Kornat, Polityka równowagi 1934-1939. Polityka między Wschodem a Zachodem, Kraków 2007. 
Piotr Korduba

bardziej dopytuje o możliwość sztuki narodowej, wiele osób dopytuje zatem, czy wnętrza i meble mają dostatecznie polski wyraz. Wiele w nich obcych wpływów. Wpływy nie są groźne, gdy trafią do środowiska na poziomie!”63.

\section{Bibliografia}

Bilewicz Hubert, Meble w Zameczku prezydenta Ignacego Mościckiego w Wiśle. Kwestia chronologii, inwentarza i atrybucji, „Porta Aurea” 2009, nr 7-8, s. 284-345.

Błachowski Aleksander, Ludowe dywany dwuosnowowe w Polsce, Toruń 1990.

Chojecka Ewa S., Pomiędzy historia a nowoczesnością. Treści ideowe Zamku Prezydenta RP $w$ Wiśle [w:] Zamek Prezydenta Rzeczypospolitej $w$ Wiśle / The Castle of the President of The Republic of Poland in Wista, red. Jacek Purchla, Kraków 2005, s. 11-20.

Chrzanowski Zenon, Kultura mieszkalna, Warszawa 1911.

Das schöne Heim. Deutsche Wohnvorstellungen zwischen 1900 und 1940 in Bild und Text, Hg. Andreas K. Vetter, Heidelberg 1999.

Dzisiejsze mieszkanie. Katalog pokazu. Miejskie Muzeum Przemystu Artystycznego, Lwów, kwiecień-maj 1930, oprac. Henryk Cieśla, Lwów 1930.

Gładkowska Ewa, Ostpreussiche Bauernteppiche - Die Geschichte einer Polemik über Ihre Herkunft [w:] Die Etablierung und Entwicklung des Faches Kunstgeschichte in Deutschland, Polen und Mitteleuropa (anlässlich des 125-jährigen Gründungsjubiläums des ersten Lehrstuhls für Kunstgeschichte in Polen), Hg. Wojciech Bałus, Joanna Wolańska, Birte Pusback, Warszawa 2010, s. 557-569.

Hahm Konrad, Ostpreußische Bauernteppiche, Jena-Berlin 1937.

Hirth Georg, Das deutsche Zimmer der Renaissance. Anregungen zu häuslichen Kunstpflege, München 1882.

Hirth Georg, Das deutsche Zimmer der Gotik und Renaissance, des Barock-, Rococo-, und Zopfstils Anregungen zu häuslichen Kunstpflege, Leipzig 1899.

Huml Irena, Warsztaty krakowskie, Wrocław-Warszawa-Kraków 1973.

Huml Irena, Polska sztuka dekoracyjna XX wieku, Warszawa 1978.

Huml Irena, Ład w Katowicach [w:] Polskie art déco, red. Zbigniew Chlewiński, Płock 2015, s. 26-41.

Jurga Halina, Kilimy, gobeliny, dywany [w:] Spółdzielnia Artystów „Ład” 1926-1996, t. 1, red. Anna Frąckiewicz, Warszawa 1998, s. 154-179.

Karolczak Waldemar, Poznańskie magazyny mebli i ich oferta na przełomie XIX/XX wieku, „Kronika Miasta Poznania” 1999, nr 4, s. 76-92.

Kilimy polskie od XVIII do XX wieku, red. Maria T. Michałowska-Barłóg, Poznań 2008.

Kircher Ursula, Von Hand gewebt. Eine Entwicklungsgeschichte der Handweberei im 20. Jahrhundert, Marburg 1986.

Kizik Edmund, Verein für kaschubische Volkskunde w latach 1907-1914. Ludoznawstwo kaszubskie między niemieckością a polskością, „Zapiski Historyczne” 2015, z. 2, s. 31-54.

\footnotetext{
${ }_{63}$ Zygmunt Skibniewski, Architektura wnętrza. Uwagi o wystawie w Instytucie Propagandy Sztuki, „Arkady” 1937, nr 5, s. 242-243.
} 
Kizik Edmund, Współpraca Izydora Gulgowskiego z gdańskim Kunstverein w roku 1909. U źródeł ceramiki nowokaszubskiej, „Kwartalnik Historii Kultury Materialnej” 2015, poradnictwo... z. 3, s. 495-510.

Klekot Ewa, „Ład” i lud. Twórcy sztuki ludowej a twórcy „Ładu” [w:] Spółdzielnia Artystów „Ład”, t. 2, red. Anna Frąckiewicz, Narodowe Centrum Kultury [w druku].

Kluczwajd Katarzyna, Spojrzenie na Rzut. O wyposażeniu domu i wzornictwie w toruńskim wydaniu, Toruń 2002, s. 15-16.

Korduba Piotr, Danziger Möbel und Innenräume im 19. und 20. Jahrhundert und ihre polnischen und deutschen Konnotationen [w:] Visuelle Erinnerungskulturen und Geschichtskonstruktionen in Deutschland und Polen 1800 bis 1939, Hg. Robert Born, Adam S. Labuda, Beate Störtkuhl, Warszawa 2006, s. 305-321.

Korduba Piotr, Ludowość na sprzedaż. Towarzystwo Popierania Przemysłu Ludowego, Cepelia, Instytut Wzornictwa Przemysłowego, Warszawa 2013.

Korduba Piotr, Wnętrza gdańskie poza Gdańskiem [w:] Gust gdański, red. Bronisława Dejna, Jakub Szczepański, Gdańsk 2004, s. 150-164.

Korduba Piotr, Wystawa tkanin „Polska sztuka tkacka” w Instytucie Propagandy Sztuki w 1938 r. [w:] Tkaniny orientalne w Polsce - gust czy tradycja?, red. Beata Biedrońska-Słotowa, Warszawa 2011, s. 23-32.

Kornat Marek, Polityka równowagi 1934-1939. Polityka między Wschodem a Zachodem, Kraków 2007.

Kulpińska Katarzyna, Każdy może kupić sobie oryginalny drzeworyt. Grafika na ścianie mieszkania w latach dwudziestych i trzydziestych dwudziestego wieku [w:] Polskie art déco, red. Zbigniew Chlewiński, Płock 2017, s. 155-174.

Leśniakowska Marta, Modernistka w kuchni. Barbara Brukalska, Grete Schütte-Lihotzky $i$ „polityka kuchenna” (wstęp do architektury modernizmu), „Konteksty. Polska Sztuka Ludowa" 2004, nr 1-2, s. 179-196.

Morozowicz-Szczepkowska Maria, Wnętrze polskiego domu dawniej a dziś, Warszawa 1928.

Mościcka Izabela, Obraz, grafika czy malowidło ścienne [w:] Polskie art déco, red. Zbigniew Chlewiński, Płock 2017, s. 175-188.

Muthesius Stefan, The „altdeutsche” Zimmer, or Cosiness in Plain Pine. An 1870s Munich Contribution to the Definition of Interior Design, „Journal of Design History” 2003, vol. 4, s. 269-290.

Schultze-Naumburg Paul, Das Gesicht des deutschen Hauses, München 1929.

Schultze-Naumburg Paul, Jak urządzić i ozdobić mieszkanie, przeł. A. Krasnowolski, Warszawa 1908.

Spółdzielnia Artystów „Ład” 1926-1996, t. 1, red. Anna Frąckiewicz, Warszawa 1998.

Szuman Stefan, Dawne kilimy w Polsce i na Ukrainie, Poznań 1929.

Świechowski Zygmunt, Awangarda na usługach elity władzy. Wystrój i mobiliaż Zamku Prezydenta RP $w$ Wiśle [w:] Zamek Prezydenta Rzeczypospolitej $w$ Wiśle / The Castle of the President of The Republic of Poland in Wisła, red. Jacek Purchla, Kraków 2005, s. 221-228.

Vetter Andreas K., Die Befreiung des Wohnens. Ein Architekturphänomen der 20er und 30er Jahre, Berlin 2000.

Warsztaty Krakowskie 1913-1926, red. Maria Dziedzic, Kraków 2009. 
During the interwar period, Polish interior design consulting stimulated our national achievements; however, it did not happen in isolation from foreign trends. One of the most distinct influences were the accomplishments of German residential culture. The previous German influence had been coloured by negative associations: with the period under German occupation on the one hand, and with the outdated apartment functions and aesthetics based on the residential culture of the late $19^{\text {th }}$ century and its neo-style furnishings on the other. Yet as early as in the late 1920s, a completely different German horizon began to appear, gaining popularity in the 1930s. Ever since then German interior design and furnishing achievements became synonymous with rationality, functionality, and even, broadly speaking, general modernity. It is therefore difficult to present an unambiguous diagnosis of the German-Polish relationship relating to habitation during the interwar period. On the one hand it was difficult to escape the tensions generated by political and national prejudices, and on the other, to evade the neighbouring German cultural achievements and their real and positive impact on many Polish accomplishments, especially in the realms of architecture and habitation. One may say that the emotional antagonism which could be seen during the 1920s faded with time and was displaced, at least among experts, by an awareness of the nearby existence of successful models which, thanks to specialist literature and books, along with visiting fairs and exhibitions, were well known and appreciated. 